\title{
Education for multicultural citizens in Indonesia: policies and practices
}

\section{R. Raihani}

To cite this article: R. Raihani (2017): Education for multicultural citizens in Indonesia: policies and practices, Compare: A Journal of Comparative and International Education, DOI: 10.1080/03057925.2017.1399250

To link to this article: https://doi.org/10.1080/03057925.2017.1399250

曲 Published online: 20 Nov 2017.

Submit your article to this journal $\sqsubset$

Q View related articles $₫$

View Crossmark data $\circlearrowright$ 


\title{
Education for multicultural citizens in Indonesia: policies and practices
}

\author{
R. Raihania,b (D) \\ aFaculty of Islamic Education and Teacher Training, UIN Sultan Syarif Kasim Riau, Pekanbaru, Indonesia; ${ }^{\text {b School }}$ \\ of Social Sciences, The University of Western Australia, Perth, Australia
}

\begin{abstract}
This paper examines how education in Indonesia can help create tolerant and multicultural citizens through the analysis of policies and practices. After the political shift in 1998, Indonesia issued education law No. 20 in 2003 which contains, though vague, a couple of articles that can underpin the development and implementation of multicultural education. This is a 'spirit' of multicultural education, which has been interpreted in subsequent regulations and decrees. In this paper, the author explores how these policies and school curricula have been translated into practices. The author conducted a series of ethnographic fieldwork in two provinces, Yogyakarta and Central Kalimantan, visiting six different schools: four religious (three Islamic and one (atholic), one state secular and one state vocational. The findings suggest that there were inconsistencies between policies and practices of multicultural education due to a lack of explicit policies and incapable education decision-makers and teachers.
\end{abstract}

\section{KEYWORDS}

Indonesia; multicultural education; citizenship;

Islamic school

\section{Introduction}

Indonesian education has experienced significant changes, particularly since the Reformasi era, which began in 1998 following the forced resignation of President Suharto. One of the remarkable changes is the issue of the new education law in 2003 (Kementrian Pendidikan Nasional 2003). In this law, the autonomy, which entails democratisation, of education was introduced following the political decentralisation policy of 1999. Higher participation of the community (masyarakat) in education is required in the Law and much of the authority in the central education office is delegated to the lower authorities, i.e. district education offices and schools. With regard to cultural diversity, although the Education Law of 2003 does not explicitly mandate a programme of multicultural education, there are strong indications in the law that suggest the importance of education that promotes diversity, tolerance and peace. There is ample opportunity based on the law for schools to develop and implement this education.

The complexity of Indonesian society, which consists of rich cultural and religious diversity and the recent development of Indonesian Islam, which has made a conservative turn 
(explained in the following section), calls for the urgency of multicultural education in schools. Several studies on this topic indicate that Indonesian education has neither adopted nor implemented the clear concept of multiculturalism to be taught in schools. Bhinneka Tunggal Ika (Unity in Diversity), the Indonesian national motto, has not been clearly operationalised in education (Tilaar 2005). To mention a few reasons, as Raihani (2011) points out, the government did not develop a clear vision for multicultural education which can tie other components of schools cohesively to educating pupils about multiculturalism. Hoon (2013b) implies the absence of dedicated teachers in teaching multicultural values in students. Other studies such as Listia, Arham and Gogali (2007) and Lie (2000), which were concerned with the school curriculum, found that its contents did not provide ample room for teaching multicultural concepts and values. Indoctrination and truth claims were common issues in religious education which limited critical thinking and a comparative approach to teaching religion (Listia and Gogali 2007). When school education did not promise much, Parker (2010) found the positive contribution of non-governmental organisations (NGOs) to the development of education for tolerance among schoolchildren.

The previously mentioned studies were very useful in shedding light on how multicultural education in Indonesia has been developed and implemented, yet remained partial in their approach to such education. In this paper, therefore, I would like to explore how multicultural education in Indonesia has been developed and implemented by looking at relevant policies and practices as points of analysis. It is important to explore both aspects of the education in order to better understand the consistencies between the two. By doing so, I believe that this study will be able to portray a more comprehensive picture of multicultural education in Indonesia. To this end, after building a theoretical framework of multicultural education, I will first describe briefly my analysis of several policy documents, including some relevant government regulations and school curricula. Second, I will explore how Indonesian schools practise multicultural education. In this regard, I will explore the curricula of related subjects, classroom instructions, school leadership and school culture. Understanding these practices will help us understand first how practices match with or deviate from policies; and, second, under the school autonomy framework, how schools develop awareness of the reality of cultural diversity and subsequently develop education for diversity correspondingly.

\section{Multicultural education: curricular approach and whole-school approach}

According to Bhikhu Parekh, multicultural education was initially a response to Eurocentrism in the field of education in Europe both in terms of the content and ethos of education (Parekh 2006). Parekh identifies several limitations of this Euro-monocultural education. This education does not arouse students' curiosity about other cultures. It also stifles the growth of the critical faculty of students. Students of monocultural education tend to develop a judgemental attitude towards other cultures from their own cultural perspectives. Besides, monocultural education has the potential to breed arrogance, insensitivity and racism in students. Bhikhu Parekh concludes that monocultural education is simply not a good education because a good education is one that 'exposes pupils to different conceptions of a good life, systems of belief and modes of conceptualising familiar experiences, [and] gets them to enter into the spirit of other cultures' (Parekh 2006, 227). 
Reading the literature on the topic of multicultural education, I conclude that there are two dimensions of that education. First, multicultural education is focused on the development of the understanding of cultural diversity in order to develop the corresponding attitudes of students. This dimension falls under Gibson's second approach to multicultural education, i.e. education about cultural differences to promote better cross-cultural understanding (Gibson 1984). In this dimension, the process of multicultural education is highly concentrated on the curriculum as a centrum of knowledge development. In line with this, Parekh argues that the most important strategy for multicultural education is working on developing curricula which teach cultural diversity and understanding to students (Parekh 2006, 227-230). A multicultural curriculum has to meet two conditions. One is that it should not be unduly narrow, for it should familiarise students with the representative forms of different cultures so that they can follow up the rest on their own. The other is that the process of imparting the curriculum should trigger a fruitful dialogue in that students are able to develop their own critical judgements on what is being taught. Parekh's recommendation seems to be focused on the development of the cognitive domain of students to have a proper understanding of different cultures, religions, ways of life, societies and so forth, which in turn leads them to make critical reviews and judgements. These are capital for them to develop positive attitudes toward multiculturalism. From a critical multiculturalism perspective, however, a school curriculum should raise in students the critical awareness of racial, gender and class representations and engage them in discussions of the discursive construction and socio-political images of these images. The curriculum should not only contain critical descriptions of minorities, but also push students of the majority to think critically about their status as the majority.

Second, multicultural education is also focused on the creation of school and its environment as a place for students from various backgrounds to experience equally good quality education. In this dimension, every student regardless of race, culture, religion, gender and class is provided an equal opportunity to develop his or her potential. This dimension of multicultural education works on various school aspects to transform schools into multicultural grounds for all students. This dimension is supported by James Banks in his definition of multicultural education as 'an inclusive concept used to describe a wide variety of school practices, programmes and materials designed to help children from diverse groups to experience educational quality' (Banks 1986a, 222). Relating this second dimension to the first one, Banks $(1986 \mathrm{~b}, 16)$ argues:

Strategies that are effective in reducing racism in the curriculum and the school must be comprehensive in scope and focus on all aspects of the school environment, including the hidden curriculum, institutional norms, school policy, the counselling program, assessment and testing procedures, the formalised course of study, teaching methods and materials, and the attitudes and expectations of the school staff.

This second dimension accommodates the critical multiculturalism argument against structural racism and social injustice in schools through the reform of such various aspects of education (May and Sleeter 2010). It is concerned not only with formal and non-formal programmes of school education, but also with school structures and cultures.

The above two dimensions of multicultural education suggest that multicultural education is beyond a particular programme of school, but rather it is systematically comprehensive strategies. It involves a whole-school approach in the process of development and implementation. This whole-school approach include the ethos of the school including 
school culture and values, its curriculum and instruction, its assessment and evaluation procedures, its language policy and its approach to cultural diversity. According to James Lynch (1986), this approach will enable students from minority groups to maintain their unique identities and at the same time achieve socialisation with others. This approach will also encourage the majority students to rethink their status and develop appropriate attitudes towards cultural diversity. Cooper et al. (1998) suggest the involvement of such elements as schools' policy, teachers, management, parents, students and school councils in various activities and processes to approach effective multicultural education. This is possibly to guarantee consistency in the development and implementation of multicultural education programmes. Regular discussion amongst staff and teachers as well as other community members regarding the planning and implementation of multicultural education is one of the suggested activities.

Based on the discussions made here, I would like to conceptualise a whole-school approach to multicultural education which incorporates six interrelated elements of school. The interrelated elements are: (1) school vision and policies; (2) curriculum and instruction; (3) leadership and management; (4) capacity and culture; (5) student activism; and (6) collaboration with wider communities. Central to this approach are a school vision and policies which serve as directions and guidelines for multicultural education. Leadership plays a role in orchestrating the other elements to realise the vision, while management ensures the stability of the process by enacting its managerial functions. The quality of the curriculum and teaching are the heart of the process, and provide the main resource for children to learn to understand cultural diversity and develop appropriate attitudes to it. The curriculum objectives and content which explicitly contain teachings of multiculturalism are a reflection of the school's vision, and the teaching facilitates the attainment of such objectives. The quality of the teaching is not only about teaching with the right pedagogical skills and technicalities, but is also about having whole-hearted values of respect for the uniqueness, and the needs of, every pupil. High-quality teaching will not be achieved without continuous professional development for teachers and other staff to build their capacity in processing multicultural education. High-quality teachers are those who are able to create supportive cultures for children to live with and in diversity. Deliberate and explicit actions for the creation of rituals, norms and standards consistent with multicultural education should be carried out in order to establish school cultures that support diversity. These can be conducted through student activism in both intra and extra-curricular programmes. Student activities are one of the vital elements of this approach, since their activities are the core of the school process through which they acquire knowledge, skills and values. To support the firmness and effectiveness of multicultural education, partnerships with the wider community, not limited to parents and immediate community members, complete the coherence of this approach.

In short, the curricular approach to multicultural education is not sufficient to respond to the complexity of the diverse reality of society. Therefore, in my opinion, in order not to miss the focal point of multicultural education, which is the development of knowledge and values in multiculturalism in students, a comprehensive school approach is necessary. In this paper, several related components of education - from policy to practice - are analysed within the framework of this approach.

Another important note is that the concept of multicultural education discussed here is not limited to ethnicity and culture, but is also about other identity markers such as 
religion. Religion, in the context of Indonesia, appears even more frequently than culture as one aspect of multicultural reality (Parker and Hoon 2013; Suryadinata, Arifin, and Ananta 2003). Therefore, leaving out religion in the discussion of Indonesian multicultural education will have a consequence of missing out one of the central points of diversity in the country. In this context, multicultural education is also meant as education for religious diversity.

The current social and political development in Indonesia suggests an Islamic conservative turn in the post-Suharto era. Bruinessen (2013) argues that Indonesian Islam has moved to a more conservative outlook due to, among other things, the influence of scholars returning from Middle Eastern universities, particularly those of Saudi Arabia and Kuwait, over the religious thought of many Indonesian Muslims. Further to this argument, the Islamic transnational movements have gradually weakened the centrality of two main moderate Islamic organisations - Nahdlatul Ulama (NU) and Muhammadiyah - in guiding the moderate path of Indonesian Islam. In addition, Fealy points to the counter-productive strategy by so-called 'liberal Islam' which has sparked controversies among the Muslim people, and hence, backlash from the wider Muslim community. Bruinessen (2013) and Fealy (2007) agree that the opposition to liberal Islam does not only come from anti-liberal organisations and figures, but also from figures of both moderate organisations.

The conservative turn, as briefly discussed here, has an impact on majority-minority relations. The most recent example is the imprisonment of the former Chinese Christian Governor of Jakarta - Basuki Tjahaya Purnama, popularly called Ahok - for his accused slander of one verse of the Quran.. Some analysts believe that Ahok did not intentionally debase the holy verse, but the prosecutors and judges see it otherwise, following the outcries and demands of the Islamic organisations to put him in jail. Ahok's case is another indicator of the intensifying polarisation of the majority-minority relations, particularly between Muslims and Christians in the post-Suharto era, in addition to the previous ethnic and religious conflicts such as Dayak-Madura in Kalimantan (2001) and Muslim-Christian in Ambon and Poso (1999-2001) (Klinken 2007).

\section{Visiting six different schools}

I visited six different senior secondary schools in two different provinces: Yogyakarta and Central Kalimantan. Two schools in Yogyakarta include The Enlightened Islamic Boarding School (EIBS) and Creativity State Vocational School (CSVS), while the rest were located in Central Kalimantan, including Averroes Muhammadiyah School (AMS), St Peter Catholic School (SPCS), Rose Garden State Secondary School (RGSSS) and Voice of Islam State Islamic School (VISIS). The reasons for selecting these schools were: first, they are located in two provinces where populations were diverse in terms of both culture and religion; and, second, they were respectively taken out of the existing types of secondary schools in Indonesia, i.e. general schools, religious schools and vocational schools. I conducted three stints of fieldwork each lasting two months in the two provinces, one month for each school, in the period 2009-10. With the approval of the Head of Dinas Pendidikan (Education Office) and the respective principal, I visited each school almost every school day observing day-to-day school practices and events. I wrote field notes of what I saw, heard and felt during my stay in the schools. This was a back-and-forth process (Christensen, Burke Johnson, and Turner 2011, 373) in which I completed the field notes, checked and 
edited every day before the next phase of data collection began. I took pictures to document visual activities. It is important to note that in Yogyakarta, the student body in the studied schools was dominated by Javanese Muslims with significant numbers of students from other ethnic and/or religious backgrounds, while in Palangkaraya, Central Kalimantan, the student body was quite diverse, consisting of the dominant ethnic groups, including Dayak, Banjarese, Javanese and students from various religious backgrounds, i.e. Islam, Catholicism, Protestantism and Hinduism.

I employed Focus Group Discussions (FGD) and in-depth interviews with more than 100 students, 80 teachers and 6 principals, exploring their perspectives on how school education functioned to promote cultural diversity and inculcate tolerant and multicultural attitudes. I tried to have FGDs with groups of parents in each school, but I mostly failed to do so because of the low interest of parents in attending such activities and their work commitments. So, instead, I ended up with interviewing. In each school, I interviewed 6 to 10 parents and a couple of community figures. With their permission, I recorded the conversations to ease the process of data analysis later. During the series of fieldwork, I was assisted by young researchers in both Yogyakarta and Central Kalimantan who understood local knowledge and culture. Both research assistants played quite significant roles in helping me during the data collection, as well as coping with some local cultural issues.

I transcribed all the interviews and FGDs in the original languages in order for me to have a fuller understanding of what was being spoken and its context. I used N-Vivo to help me generate codes and categorisations based on the themes emerging from the transcribed data. This was a huge process of learning from the data before meaningful interpretations could be made. During this process, I conducted regular checks, clarifications and confirmations with data collected through other major collection methods such as participant-observation field notes, student diary collection, student writing tasks, curriculum documents, textbooks and news from both online and conventional national and local media. I used discourse analysis in this process, which allowed me to go beyond the merely written and spoken language to the social and cultural contexts for comprehensive understanding of the data.

\section{Policies and regulations around education for diversity}

The Education Law of 2003 provides sufficient basis for developing multicultural education. In my reading, there are at least three articles of the law which are understood as encouraging education for cultural diversity. One example is Article 3, which sets the aim of national education in which multicultural qualities of students are resembled in the phrase 'dan menjadi warga negara yang demokratis serta bertanggung jawab' ('and to become democratic and responsible citizens'). The phrase 'democratic and responsible citizens' indicates an educational process that upholds the values of democracy, which encourages power sharing among groups of people. Democratic citizenship guarantees the rights of individuals while also expecting them to respect the nation's and society's interests. In order to produce democratic and responsible citizens, multicultural education is necessary. '[Multicultural education] supports and extends the concepts of culture, diversity, equality, social justice, and democracy into the school setting' (Gollnick and Chinn 2009, 4).

Technically, the Ministry of Education's decree of 23 issued in 2006 serves as an operational translation of the Education Law of 2003 in regards to the standardisation of graduates' competencies from primary to junior secondary to senior secondary schools (Standar 
Kompetensi Lulusan or SKL). Three levels of the standard competencies are outlined in the decree: the standard competencies at the school level; the standard competencies at the subject group/area level; and the standard competencies at the subject level. These competencies reflect the educational outcomes students will achieve after completing the determined period of learning.

At the school level, the standard competencies of graduates are grouped into four levels: primary school; junior secondary school; senior secondary school; and vocational school. The standard competencies at the primary school level consist of 17 competencies, those at the junior secondary school consist of 20 competencies; and those at the senior secondary and vocational schools comprise 23 competencies. The list of graduates' competencies at each level of schooling similarly contains at least one multicultural competency, which is 'menghargai keberagamaan agama, budaya, suku, ras, dan golongan sosial ekonomi' (to respect the diversity of religion, culture, ethnicity, race, and social and economic groups/ classes). What differentiates each schooling level is the context in which a competency is bounded. For primary graduates, the ability to respect the mentioned diversity is bounded in the small environment context ('lingkungan sekitarnya' or their neighbourhood) appropriate for their age level, while for junior secondary graduates, that competency of respect should be demonstrated in the context of the national level. The multicultural competency for senior secondary graduates is expected to be demonstrable in the global context. It is clear that the policy of the standard competencies of graduates at each schooling level explicitly outlines multicultural competencies students will achieve after completing the determined schooling period. This is not to include other competencies outlined in the lists which are indirectly related to or supportive of multicultural education, including the citizenship competencies. For instance, senior secondary graduates are expected to be able to participate in their society and nation in a democratic way within the framework of the Republic of Indonesia. As pointed out earlier, multicultural education is a means to produce democratic citizens.

From observing this regulation, it is clear that multicultural understanding, values and attitudes are one of the targeted competencies for students to possess. This was strengthened in the curriculum centre's publication on how to develop a model of multicultural education for secondary schools (Pusat Kurikulum 2007). This book outlines objectives, visions and strategies for developing multicultural education. The book recommends the identification of subjects in which multicultural education can be integrated (10). However, from all policy documents reviewed earlier, a holistic multicultural education is absent from recommendations. The structure of students' competencies developed in the regulations indicates a curricular approach to this education, i.e. the infusion into several subjects and/ or the infusion of several topics into one or more subjects.

\section{The infusion of multicultural education (MCE) into subjects}

At the subject level, the Decree of 23/2006 outlines the list of the standard graduates' competencies for every subject included within each of the subject groups/areas. Multicultural competencies are infused into the religion, citizenship education and social sciences. Within the limited space of this paper, I will only describe two subjects, i.e. Religion and Citizenship Education, both made compulsory across schooling levels. 


\section{The Religion subjects}

Religion is a compulsory subject for students to learn in schools. As mandated in the Education Law of 2003, both state and private schools are obliged to teach students their religious teachings. However, not every school complied with this particular law for several reasons. SPCS did not provide the corresponding religion subjects for non-Catholic students; instead, the students were 'forced' to join the Catholicism subject. The clearly stated mission of the school was to teach Catholicism to its students, no matter what their religion was, even though, as the principal and teachers said, there was no effort to make students convert. State non-religious schools (CSVS and RGSSS) had problems with the provision of appropriate and fair learning facilities for students of minority religions. The cliché was that there was not sufficient funding allocated by the government to support the minority religion classes. Whilst EIBS and VISIS provided only the Islam subject, as there were no non-Muslim students, AMS tried to comply with the law by instructing the only three Christian students in 2009-2010 to receive their Religion lessons in community churches and asking the priests to provide the school with their evaluation reports.

In terms of the curriculum objectives of the Religion subjects, students are expected to develop an understanding of their respective religious teachings, apply the teachings in their lives, manifest them in good character and morality, and be committed to practise religious worship and rituals. The Islamic, Catholic and Protestant curricula explicitly mention the quality of students being religious in the context of multicultural Indonesia. The Islam curriculum mentions tolerance as one quality, maintaining the balance between personal and social harmony. The Catholic curriculum stresses values of peace and justice, which are commonly 'hoped by every individual of different religions'. This emphasis indicates the concern of teaching about the common ground that people of different religions share. The Protestant objective shows an awareness of the pluralist society that students live in, and aims to transform their morality to correspond to plural characteristics. This objective seems to be in conflict with the goal of evangelism implied in the curriculum's scope, that students are expected to develop missionary competencies. The Buddhist curriculum mentions 'tolerance' in its list of basic competencies, but not in its objectives. After all, the bottom line of all the curricula is the objective of nurturing religious belief in students and of making these beliefs the basis for their lives and their interactions with other human beings. With this curriculum approach, religion class is predominantly confessional and intrinsically dogmatic.

From reading the textbooks from the five religions - Islam, Catholicism, Protestantism, Hinduism and Buddhism, ${ }^{2}$ - distinctive characteristics can be summarised, as follows. First, these textbooks are informative. Significant proportions of the textbooks are allocated to inform students about religious doctrines and teachings. The Islam textbook by Erlangga, ${ }^{3}$ for example, begins each topic by presenting several verses of al-Quran relevant to the lessons. It informs readers of key teachings or doctrines contained in the verses. Second, the writing styles of the textbooks are mostly persuasive. They invite students to put their trust in the presented religious teachings. Third, in some instances, the texts contain narrative writing in order to invite students to ponder the teachings further and/or to convince them. For example, the Protestant textbook for Grade 12, published by ANDI in 2008, mentions on page 88 the story of Airlangga Wattimera who accepted Jesus Christ, but who was not free from tests in life. The story is presented to support the previous persuasive piece of writing 
about putting trust in Jesus and being optimistic about his guidance and mercy. Fourth, some of the topics are contextualised to enable students to ponder and evaluate the values and teachings contained in the texts and compare them to their life experiences. Of the textbooks of the five religion classes I collected, the contents of the Hindu textbook published by Paramita in 2005 are poorly contextualised. The textbook is highly informative, with too many complex concepts relating to Hindu teachings and dogma. The Islam textbooks are also similar. Finally, at the end of each lesson unit, there is an evaluation section in the form of either questions or assignments. This is important for teachers to understand the extent to which students have digested the lessons, even though most of the evaluation is focused on the cognitive domain of student outcomes.

As indicated earlier, the Protestant curriculum implies the evangelical capabilities of students. One of the basic competencies outlined in the curriculum indeed mentions: '[students are expected to] realise their role as messengers of "kabar baik" (good news) and peace to individuals and the community'. In the Christian tradition, 'kabar baik' is referred to the Gospel, which consists of the first four books of the New Testament. So, the messenger of 'kabar baik' is the one who spreads the teachings of the Gospel to human beings or the world. However, in the Protestant textbook, this competency is never elaborated upon. Instead, the competency of 'messenger of peace' is emphasised, and Lessons 19 and 20 are dedicated to it. Lesson 19 is entitled 'Manfaat Hidup Damai Secara Pribadi dan Kolektif' ('The Benefits of a Peaceful Life Individually and Collectively'), and 'Orang Kristen Sebagai Pembawa Damai' ('Christians as Messengers of Peace'). Categorically, this book is Ecumenical, which emphasises more social concerns and justice and peace rather than spreading the mission to the world (evangelism) (Hoon 2013a). According to the principles of curriculum development, there should be coherence between a basic outcome and lessons (that should be) developed based on such a competency (Brady and Kennedy 2003). In other words, what is designed in the lessons should correspond to the competencies outlined in the curriculum. The difference between the two in the case of this book could be due to either the difference between the religious affiliation of the curriculum developers and that of the book authors or the deliberate correction made to accommodate the national interest of social harmony.

\section{The Citizenship subject}

Citizenship education in Indonesia has been taught in a subject called Pendidikan Kewarganegaraan or PKn (Citizenship Education) since 2003 - a name change from Pancasila and Pendidikan Kewarganegaraan or PPKn (The Five Principles and Citizenship Education) since 1994, which replaced Pendidikan Moral Pancasila (Pancasila-Based Moral Education) from 1975 (Gaylord 2008, 120-122). The general objectives of the PKn curriculum across schooling levels is that students are expected to: (1) Have critical, rational and creative thinking in responding to citizenship issues; (2) Participate actively and responsibly and intelligently in society and nation, and develop an anti-corruption stance; (3) Develop democratic personalities based on Indonesian characteristics to be able to live together with other nations; and (4) Interact with other nations globally either directly or indirectly using the advancement of information and communication technology (ICT) (Kementrian Pendidikan Nasional 2006, 1-25).

In relation to cultural diversity, most of the standard competencies of graduates at primary through secondary school have been designed to develop citizens with multicultural 
understanding and abilities. However, from the list of the standard competencies of the PKn subject, primary school students are given a larger proportion of the issues of multiculturalism, whilst secondary school students are expected to master the newly developed democratic political system of Indonesia and its international relations. It is understandable, therefore, that the interviewed students and teachers of the six schools argued that this subject contained only a little of the teachings of multiculturalism and mostly focused on the Indonesian political system, such as issues of democracy, general elections, the parliament and so forth. The only discussion related to multiculturalism in the PKn secondary school textbooks was about human rights, which unfortunately focused only on the right to live with particular examples of Indonesian military massacres in East Timor and Papua (Budiyanto 2007; Santoso 2007). Although such examples conveyed criticism of the government and taught students some facts that might be unknown to them, cultural, religious and economic rights were neglected in the textbooks. This reflects the limited understanding of the authors regarding the scope of human rights. The failure to expand the scope of human rights into these aspects may lead to a limited understanding of multiculturalism which promotes equal rights of human beings.

Besides these two subjects, there are other subjects taught to students which contain teaching from multicultural education. These subjects include Sociology and Anthropology. Unfortunately, in secondary schools these subjects are only taught selectively to students of certain streams.

\section{School leadership}

The policies of multicultural education need to be translated further into actions by school leaders. From my observations and interviews with various respondents including the principals themselves, I found that the belief of the principals in cultural diversity was quite positive. They admitted that Indonesia is inherently diverse in cultures and faiths, and that respect and tolerance are keys to the country's unity. Their positive belief in and understandings of diversity were influenced greatly by their exposure to such differences. They learnt a great deal from such experiences about cultural and religious diversity and how to respond to it. Both Palangkaraya and Yogyakarta are places characterised heavily by cultural and religious diversity. Parekh $(2006,226)$ indeed suggests that exposure to cultural diversity is most likely to contribute to positive beliefs and attitudes to it. These positive beliefs and understandings of diversity on the part of the school leaders could be an underpinning capital for them to begin to believe that every student matters (Leithwood and Jantzi 2000). The principals of the current study generally believed that there should not be discrimination against students because of their different cultural and economic backgrounds, even though some of the school practices indicated the contrary.

There were also several dimensions or qualities of the principals' leadership which are quite promising for the development of multicultural education. In general, the principals possessed the qualities and attributes which enabled them to lead and manage schools with multicultural characteristics. They had visions for what schools should look like in the future, were quite open and honest in building personal and organisational relationships, and were trustworthy, with the exception of the RGSSS's principal who had an issue of financial transparency. The principals also generally demonstrated the ability to foster the professional development of teachers in terms of teaching knowledge and skills, although 
in some cases they could be rather selective. Teachers improved their competencies through external and internal programmes of professional development. With the requirements of the new curriculum, teachers of the schools have been undertaking training and courses in democratic learning, which enables them to treat students as subjects of the educational process. With regard to teacher professional development for multicultural education, however, they did not have concrete conceptualisations of the programmes they wanted to create. The programmes that teachers usually took part in were developed and run by external agencies.

Nevertheless, there were problems concerning the equal distribution of jobs and responsibilities in VISIS among teachers of different ethnic backgrounds. Teachers accused the principal of favouring Javanese teachers compared to others. In EIBS, several teachers complained about differentiation in matters involving decision-making and distributing teaching hours between internal (orang dalam) and external (orang luar) teachers. In this regard, internal teachers were referred to as those who were members of the leader's family and alumni of the pesantren, while external ones were those identified as outside these two groups.

Some of the leadership policies and practices remain highly influenced by religious and ethnic factors. Making jilbab (Islamic headscarf) a compulsory uniform for Muslim students in CSVS was an example of how religion dictated the school leadership. Although it is the right of Muslim students to wear the jilbab, public schools where students originate from more than one religious background should not change that right into an obligation. Ethnic biases had also currently emerged more strongly. The father of a student from RGSSS, a high-ranked official in Palangkaraya, explained that ethnic biases have overwhelmed bureaucracies in the area. Putra daerah (sons of the soil) had always been prioritised over other people despite their lack of competence. Indeed, in the current stream of decentralisation, these religious and ethnic identities have become more visible and solidified in the political sphere (Aspinall and Fealy 2003). They have been arbitrarily played upon by many politicians to gain political profit, even though their rhetoric indicates the opposite. The education bureaucracies would not seem to be an exception to this contemporary phenomenon.

In VISIS, students with a stronger academic performance and economic advantage were grouped together and segregated from the 'regular' students. These groups were called 'kelas model' (model groups), serving the school's ambition to produce small groups of talented individuals. VISIS set two criteria for students to be eligible for entry to this exclusive group, namely: intelligence shown in academic performance, particularly in math and natural sciences; and the ability to pay more than regular students did - a kind of ability-wealth grouping. Grade 10 students of this kind were projected to choose Natural Sciences (NS) later in Grade 11. The school allocated two groups in each grade to become a 'privileged student community'. These privileged groups enjoyed more complete and 'luxurious' multimedia learning facilities and smaller class sizes - 25 compared to 35-40 - whilst others did not. When this issue was raised in student interviews and FGDs, almost all regular students interviewed expressed critical perspectives.

What has been presented here reflects the failure of the schools to create social justice among students. Students could barely find schools where they were treated fairly and justly, whether they came from an economically advantaged or disadvantaged family. What they found in society about social class differences and differentiation was also manifested in the school environment. They were not given equal opportunity, equal facilities and equal classroom instruction. Unfortunately, the schools' principals and teachers denied this 
inequality, arguing that there had not been any complaint by students regarding the grouping. They demonstrated passive attitudes towards the particular feeling and perceptions of the grouping policy. As they admitted, no evaluation whatsoever had been conducted to gather information about how students respond to, and experience, school policies and practices. Thus, different outcomes between intelligent/rich students and slow/poor students were not because of their talent, but more because of the differentiated school processes and services.

\section{Classroom instructions}

Not all the teachers in the six schools understood the importance of multicultural education. Through FGDs, only a few teachers admitted to infusing multicultural values and understanding in their classroom teaching. They were from the subjects of Religion, PKn, Sociology and Anthropology. In contrast, teachers of natural sciences and mathematics who attended FGDs acknowledged that multicultural education even by way of infusion was not part of their teaching. They argued that it was not mandated in the curriculum, that the overloaded curriculum hindered them from inserting other materials or topics into it, and that the pressure of the National Evaluation (Ujian Nasional, UN) forced them to be focused on preparation.

Teachers who claimed to be concerned with multicultural education, however, could not fully demonstrate teaching cultural diversity in classroom practices. In the subjects of Islam, Catholicism, Protestantism and Hinduism, for example, not all of the teachers demonstrated the ability to relate lessons to the values of religious and cultural diversity. Even in topics related to religious diversity in Indonesia, some of them tended to warn students about the danger diversity posed to their own faiths. Therefore, the issue of maintaining identity was quite a big concern for the teachers, as they expressed during the interviews. The endorsement of maintaining religious identity is indeed a characteristic of the confessional approach to religious teaching, which is predominantly used in Indonesia.

There were, however, exceptional cases in which some particular teachers demonstrated excellent understanding and teaching strategies for multiculturalism and tolerance. In SPCS, as I observed, Sr Angela exhibited a comparative approach to teaching religion, even though she taught within the context of a strict Catholic school. She argued for her choice of this method:

When discussing human rights as part of the curriculum, I usually ask students from other religions to go to their informal religious teachers or priests at home to have an interview, for example, about the death penalty. They present their findings to the class, and everyone, including me, learns. There are many things that I did not know before about Islam, for instance.

Sr Angela's method of providing comparative insights to her students should be seen as a compromise strategy to overcome the school's structural restriction of disallowing other religious teachings in her school, as indicated earlier. Her teaching practice is also a strong indication that the teacher can be a powerful actor in teaching for tolerance, as classroom processes are mostly dependent upon him or her (Doorn-Harder 2007).

Also included in exceptional teaching practices is what I observed in Sociology in EIBS. One young teacher, Siti Aisyah, demonstrated an excellent teaching strategy which engaged students in discussions. I saw students exploring and exchanging opinions and reasons on the topic of 'market' in a lively manner. Some of them debated others, and learnt concepts of 
interaction, assimilation and multiculturalism through this topic. This reflects the pedagogy of multicultural education that treats students as subjects of education who can construct knowledge in the context of the society and culture in which they live. The principles of teaching in multicultural education are focused on the meaning-making process, and teachers should help students in this process. Teachers also need to be aware of the following objectives: developing students' identities as individuals of worth; valuing differences of opinions; understanding different perspectives and their factors; learning about one's heritage; promoting global ways of thinking and understanding the interdependence of humanity; and recognising and accepting the responsibilities of a citizen in a multicultural society (Tiedt and Tiedt 2010).

\section{Religious school culture}

All the principals and teachers of the six schools were proud of having created religious culture in their respective school. For example, in non-religious RGSSS, one aspect of the vision was to create a school with a religious nuance, which according to Mr Willy, the Protestantism teacher, was mandated by the government. The frequently repeated reason for the creation of the religious school culture was that through religion, students will have a firmer foundation to develop to become individuals with strong moral characters. Religion is seen as the source of ethics and values. This intensive creation of religious culture corresponds to the general development of Indonesian society which indicates the thickening of public piety through the display of religious symbols (Fealy 2008). In other words, the captive market of schools has become more 'religious'.

There were several methods employed by the six schools to create the religious school culture, including celebrating religious festivities, implementing religious extra-curricular activities, establishing students' religious groups and enforcing religion-based student conduct. Let us take one of these methods as an example. Celebrating religious festivities became almost compulsory for the schools for the purpose, as the principals and teachers believed, of internalising religious beliefs and values. In schools where the student body consisted of diverse religious backgrounds like CSVS and RGSSS - but not SPCS where only Catholic religious ceremonies were held - the celebrations were also diverse, meaning that all religious groups were allowed to celebrate their religious festivals. Yet, even though in CSVS the celebrations were organised by the respective groups, in RGSSS there were initiatives among students to involve members of different religions in the committees. For example, in Christmas celebrations, some Muslim students were involved in the committee, and Christians were engaged in the 'Eid al-Fitr festival.

Indeed, in RGSSS, there seemed to be a high level of understanding among religious groups, particularly in terms of religious celebrations. During the festivals, they exchanged visits, paid warm greetings and enjoyed meals provided by the host. The use of technology, such as sending short messages through mobile phones and writing on friends' Facebook walls to express greetings, was another feature of harmonious interreligious relations exhibited by the school's students and teachers. Fathi, a Muslim teacher, was convinced that religious celebrations were now merrier, and teachers had visiting programmes during these seasons as well. It was interesting to hear that during Christmas Christian teachers or students provided two types of meals at home anticipating Muslim relatives' and friends' visits, namely halal and non-halal meals. They processed and presented the meals separately 
so that there would not be any suspicion from fellow Muslims. Suta, a Hindus teacher from Bali, counted a couple of million rupiahs to spend on meals, anticipating his colleague teachers and students would visit his home during the Hindu festival day, Galungan.

While RGSSS did not seemingly have a problem with regard to the creation of religious culture - apart from the structural provision of religious instruction as mentioned earlier - other schools where diverse religious backgrounds existed, like SPCS, CSVS and AMS, displayed the problematic issue of whose culture was being represented in the school culture. In SPCS and AMS, this issue was responded to by using the argument that these schools were religious schools, so that there was no need, according to the principals and teachers, to represent in school culture religions other than the official religion of the schools. In RGSSS, I did not see religious symbols displayed in classrooms except in the school's Islamic prayer room, because it was school policy not to associate school public spaces with any religion or faith. In CSVS, however, the Catholic minority groups suffered from under-representation in the school culture, while the Islamic presence was felt very strongly. The Islam-based student conduct such as the jilbabisasi (making jilbab compulsory for female Muslims) and Islamic calligraphy in classrooms indicated the conscious efforts of the school to create an Islamic culture in the school, while in the Christian prayer room, there was not a single Christian symbol displayed.

\section{Conclusions}

The above discussions shed light on the issues around policies and practices of multicultural education. By definition, multicultural education in the context of Indonesia is not limited to covering issues of culture, but inclusively and even more importantly deals with religion as an important identity marker and a source of values for life. Although religion is often misused for group politics, its importance is always manifest in the interactions of most school members and stakeholders. Therefore, as this study confirms, multicultural also means multireligious in the Indonesian context.

This study suggests that there were inconsistencies between policies and practices. While the Education Law of 2003 provides sufficient foundation for, and the policies of the national education standards mandate, education that is concerned with and respectful of diversity, the practices are quite sporadic. This means that there was no consistent articulation in the implementation of multicultural education at the level of schools. For this inconsistency, I draw several trends from this study, even though it was conducted at six different schools general, religious, state and public. First, many of the teachers in the six schools studied did not use education that promotes tolerance and diversity as part of their subject curriculum; nor did they believe that multicultural education is one of their educational responsibilities. Even within the subjects that contained topics of, or were related to, cultural and religious diversity, not all the teachers were able to demonstrate convincing practices that reflected a sound understanding of multicultural education. Some of these teachers developed the feeling in themselves and in students of being threatened by diversity, particularly religious differences. They warned students about the dangers of other cultures and religions toward their own identities. They often sent the message of the importance of strengthening and preserving faiths and values, which unfortunately was translated into being cautious of other cultures and religions. By repeating this cautious message, teachers - consciously or not - developed prejudices between cultural or religious groups, a practice that definitely 
goes against one of the principles of multicultural education, i.e. the eradication of prejudice (Banks 2010). However, as depicted earlier, younger teachers who graduated from highly regarded education universities demonstrated higher spirit, stronger commitment and more creativity in teaching. They were willing to interact with students more positively and collegially in a way that aroused students' motivation for learning. They used more of a variety of methods, and some demonstrated more individualised methods depending on the needs of individual students, even though the class sizes that generally ranged from 35 to 40 students very often made it difficult for them to implement various and/or individualised teaching methods and strategies.

Another trend is that school leadership in the six schools also failed to provide clear directions and guidelines of how to set up education for diversity. Almost all the school leaders, however, had successfully elevated the schools to the status of reputable educational institution. With the competencies and skills they possessed, the principals were actually potential orchestrators of the facets of the schools to aim for the development of multicultural education. Most of them were aware of the importance of this education, and revealed a commendable vision for it, at least as expressed during the interviews. The problem seemed to lie in the understanding of the school leaders of how to execute the vision into more strategic and systemic plans and programmes. They failed to show consistencies between the programmes or practices and the vision. Therefore, many of the programmes or school practices often entailed social injustices between students, like the student grouping discussed earlier.

Also, the creation of school culture in most of the studied schools was found to have been focused on the majority's religious culture regardless of ethnicity. This is an unfair practice for minority groups that suffered from a lack of recognition within the school culture. This confirms the problems of inconsistent policies and practices in multicultural education and a lack of the school leadership's multicultural vision. In one perspective, the creation or re-creation of religious school culture can be seen as the religio-isation of social spheres, including schools, in Indonesia following the collapse of the Suharto regime. Democratisation begun shortly after that has opened a wide channel for religious groups to pursue their agendas. The religio-isation seems to be on the side of the majority, as had happened in the schools. From another perspective, the intensified creation or re-creation of religious school culture suggests the vital position of a non-written curriculum in internalising beliefs and values, and hence developing desired attitudes and behaviours of students. Religious groups in the schools seemed to understand this very well, and therefore competed with each other to design various religious activities to support the creation of such a culture. Again, the majority survived better. An interesting case, however, was found in SPCS where the majority students came from a Protestant background, but the school culture created was oriented to Catholicism. In this case, a numeric minority dominated the school life because of the structural power they possessed.

In short, considering both the complex construction of Indonesian society and recent development of its interethnic and interreligious relations, multicultural education is vital to nurture appropriate and supportive values to cultural and religious diversity. In this paper, I have shown the political willingness of the Indonesian government to develop, though not as comprehensively as they should be, policies of multicultural education. However, the translation of such policies into practices remain inconsistent at the level of school education. The practices indicate a sporadic or partial approach to the development and 
implementation of multicultural education. The Indonesian government needs to redirect its policies and practices towards a more holistic approach to multicultural education by engaging all school elements to move forward to help create citizens who live harmoniously in, and contribute positively, to multicultural society.

\section{Notes}

1. This study, however, was conducted a few years before such heated political contestation. Although terms of policies on multicultural education had not changed significantly during the previous years, the findings of this study would possibly have been different particularly with regard to the majority-minority relations and religious teaching.

2. I was only able to collect the textbooks of these five religions. Whilst the religions acknowledged constitutionally in Indonesia also include Confucianism, I have not found Confucianism textbooks. There were no students of this religion in the schools I studied.

3. These are the full references for the textbook of each religion:

Margiono et al. (2007). Pendidikan Agama Islam: Penuntun Hidup Untuk SMA (The Islamic religion education: guidance of life for senior secondary school students) (Jakarta: Yudhistira). Three volumes for Grades 10, 11, 12;

Syamsuri (2007). Pendidikan Agama Islam untuk SMA (The Islamic religion education for senior secondary students) (Jakarta: Erlangga). Three volumes for Grade 10, 11, 12;

Adisusanto et al. (2007). Perutusan Murid-Murid Yesus: Pendidikan Agama Katolik untuk SMA/SMK (Disciples of Jesus: the Catholic religion education for senior secondary and vocational school students). (Yogyakarta: Kanisius). Six volumes for Grades 10, 11, 12;

Engel et al. (2007). Teladan Kehidupan: Pendidikan Agama Kristen (The example for life: the Christian religion education). (Yogyakarta: ANDI). Three volumes for Grades 10, 11, 12;

Team (2005). Buku Pelajaran Agama Hindu Untuk SLTA (The textbook for Hinduism lessons for senior secondary students) (Surabaya: Paramita). Three volumes for Grades 10, 11,12 .

\section{Disclosure statement}

No potential conflict of interest was reported by the author.

\section{ORCID}

R. Raihani (D) http://orcid.org/0000-0002-1636-0727

\section{References}

Aspinall, Edward, and Greg Fealy. 2003. Local Power and Politics in Indonesia: Decentralisation \& Democratisation. Singapore: Institute of Southeast Asian Studies.

Banks, James A. 1986a. "Multicultural Education and Its Critics: Britain and the United States." In Multicultural Education: The Interminable Debate, edited by Sohan Modgil, Gajendra K. Verma, Kanka Mallick and Celia Modgil, 221-231. London: The Falmer Press.

Banks, James A. 1986b. "Multicultural Education: Development, Paradigms and Goals." In Multicultural Education in Western Societies, edited by James A. Banks and James Lynch, 2-28. London: Holt, Rinehart and Winston.

Banks, James A. 2010. "Multicultural Education: Characteristics and Goals." In Multicultural Education: Issues and Perspectives, edited by James A. Banks and Cherry A. McGee Banks, 3-30. New Jersey: Wiley. 
Brady, Laurie, and Kerry Kennedy. 2003. Curriculum Construction. $2^{\text {nd }}$ ed. French Forest: Pearson Prentice Hall.

Bruinessen, Martin van, ed. 2013. Contemporary Developments in Indonesian Islam: Explaining the "Conservative Turn". Singapore: Institute of Southeast Asian Studies.

Budiyanto. 2007. Pendidikan Kewarganeraan Untuk SMA Kelas X, XI, XII (three books) [Citizenship Education for Senior Secondary School Students for Grades 10, 11 and 12]. Jakarta: Erlangga.

Christensen, Larry N., R. Burke Johnson, and Lisa A. Turner. 2011. Research Methods, Design, and Analysis. Eleventh ed. Boston, MA: Allyn \& Bacon.

Cooper, Maxine, Eva Burman, Lorraine Ling, Cveta Razdevsek-Pucko, and Joan Stephenson. 1998. "Practical Strategies in Values Education." In Values in Education, edited by Joan Stephenson, Lorraine Ling, Eva Burman and Maxine Cooper, 161-194. London: Routledge.

Doorn-Harder, Nelly van. 2007. "Teaching Religion in the USA: Bridging the Gaps." British Journal of Religious Education 29 (1): 101-113.

Fealy, Greg. 2007. "A Conservative Turn." Inside Indonesia. Accessed 15 July. http://www. insideindonesia.org/a-conservative-turn.

Fealy, Greg. 2008. "Consuming Islam: Commodified Religion and Aspirational Pietism in Contemporary Indonesia." In Expressing Islam: Religious Life and Politics in Indonesia, edited by Greg Fealy and Sally White, 15-39. Singapore: Institute of Southeast Asian Studies.

Gaylord, Wendy A. 2008. "Reformasi and Teachers' Implementation of Civic Education in West Sumatra, Indonesia." Doctor of Philosophy Unpublished, Educational Leadership \& Policy Studies of W.W. Wright School of Education.

Gibson, Margareth Alison. 1984. "Approaches to Multicultural Education in the United States: Some Concepts and Assumptions." Anthropology and Education Quarterly 15 (1): 94-119.

Gollnick, Donna M., and Philip C. Chinn. 2009. Multicultural Education in a Pluralistic Society. $2^{\text {nd }}$ ed. Upper Saddle River: Merrill is an imprint of Pearson.

Hoon, Chang Yau. 2013a. "Between Evangelism and Multiculturalism: The Dynamics of Protestant Christianity in Indonesia." Social Compass 60 (4): 457-470.

Hoon, Chang Yau. 2013b. "Multicultural Citizenship Education in Indonesia: The Case of a Chinese Christian School." Journal of Southeast Asian Studies 44 (03): 490-510.

Kementrian Pendidikan Nasional. 2003. "Undang-Undang Sistim Pendidikan Nasional Tahun 2003." Departemen Pendidikan Nasional Accessed 10 August. http://www.depdiknas.go.id.

Kementrian Pendidikan Nasional. 2006. KTSP Pendidikan Kewarganegaraan (PKn): Standar Kompetensi dan Kompetensi Dasar Tingkat SMA, MA, SMALB, SMK dan MAK [KTSP Citizenship Education: Standardised Competencies and Basic Competencies for All Types of Senior Secondary Schools]. Jakarta: Depdiknas.

Klinken, Geery Van. 2007. Communal Violence and Democratization in Indonesia: Small Town Wars. London and New York: Routledge Contemporary Souteast Asia Series.

Kurikulum, Pusat. 2007. Model Penerapan Pendidikan Multikultur Pada Jenjang Pendidikan Menengah [A Model of the Implementation of Multicultural Education at Secondary Schools]. Jakarta: Puskur Balitbang Depdiknas.

Leithwood, K., and D. Jantzi. 2000. “The Effects of Transformational Leadership on Organizational Conditions and Student Engagement with School.” Journal of Educational Administration 38 (2): $112-129$.

Lie, Anita. 2000. "The Multicultural Curriculum: Toward Education for Peace and Development." SEAMEO Jasper Fellowship Monograph Series:101-150.

Listia, Laode Arham, and Lian Gogali. 2007. Problematika Pendidikan Agama Di Sekolah [The Problems of Religious Education in School]. Yogyakarta: Institut Dian / Interfidei.

Lynch, James. 1986. Multicultural Education. London: Routledge \& Kegan Paul.

May, Stephen, and Christine E. Sleeter. 2010. "Introduction: Critical Multiculturalism: Theory and Praxis." In Critical Multiculturalism: Theory and Praxis, edited by Stephen May and Christine E. Sleeter, 1-16. New York: Taylor \& Francis.

Parekh, Bikhu. 2006. Rethinking Multiculturalism: Cultural Diversity and Political Theory. New York: Palgrave Macmillan. 
Parker, Lyn. 2010. "Religious Tolerance and Inter-Faith Education in Indonesia." Crises and Opportunities: Proceedings of the 18th Biennial Conference of the ASAA, Adelaide.

Parker, Lyn, and Chang Yau Hoon. 2013. "Secularity, Religion and the Possibilities for Religious Citizenship." Asian Journal of Social Science 41: 150-174.

Raihani. 2011. "A Whole-School Approach: A Proposal for Education for Tolerance in Indonesia." Theory and Research in Education 9 (1): 23-39.

Santoso, Joko Budi. 2007. Pendidikan Kewarganegaraan Untuk SMK Kelas X, XI, XII (Three Books) [Citizenship Education for Senior Secondary School Students of Grades 10, 11 and 12]. Jakarta: Yudhistira.

Suryadinata, Leo, Evi Nurvida Arifin, and Aris Ananta. 2003. Indonesian's Population: Ethnicity and Religion in a Changing Political Landscape. Singapore: Institute of Southeast Asian Studies.

Syamsuri. 2007. Pendidikan Agama Islam untuk SMA Kelas 10, 11, 12 [The Islamic Religion Education for Senior Secondary Students, Grades 10, 11 \& 12]. Jakarta: Erlangga.

Team. 2005. Buku Pelajaran Agama Hindu Untuk SLTA Kelas 10, 11 and 12 [The Textbook for Hinduism Lessons for Senior Secondary Students for Grades 10, 11 and 12]. Surabaya: Paramita.

Tiedt, Pamela L., and Iris M. Tiedt. 2010. Multicultural Teaching: A Handbook of Activities, Information, and Resources [The Manifesto of National Education: The Perspectives of Post-modernism and Cultural Studies]. Boston, MA: Allyn \& Bacon.

Tilaar, Henry Alexis Rudolf. 2005. Manifesto Pendidikan Nasional: Tinjauan Dari Perspektif Postmodernisme dan Studi Kultural. Jakarta: Kompas. 